\title{
Simulation Procedure for the Co-Optimization of Photovoltaic Water Pumping Systems.
}

\author{
Brian Norton \\ Technological University Dublin, brian.norton@tudublin.ie
}

Follow this and additional works at: https://arrow.tudublin.ie/dubenart

Part of the Power and Energy Commons

\section{Recommended Citation}

Norton, B., Odeh, I., Yohanis, Y. G. (2010) Simulation procedure for the co-optimization of photovoltaic water pumping systems. 2010; vol. 224, no. 5: pp. 629-640. doi:10.1243/09576509JPE844

This Article is brought to you for free and open access by the Dublin Energy Lab at ARROW@TU Dublin. It has been accepted for inclusion in Articles by an authorized administrator of ARROW@TU Dublin. For more information, please contact arrow.admin@tudublin.ie, aisling.coyne@tudublin.ie,gerard.connolly@tudublin.ie.

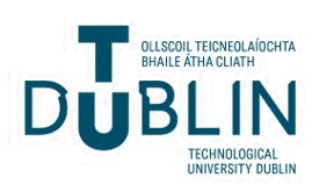




\section{Proceedings of the Institution of Mechanical Engineers, Part A: Journal of Power and Energy}

Simulation procedure for the co-optimization of photovoltaic water pumping systems

I Odeh, Y G Yohanis and B Norton

Proceedings of the Institution of Mechanical Engineers, Part A: Journal of Power and Energy 2010 224: 629

DOI: 10.1243/09576509JPE844

The online version of this article can be found at:

http://pia.sagepub.com/content/224/5/629

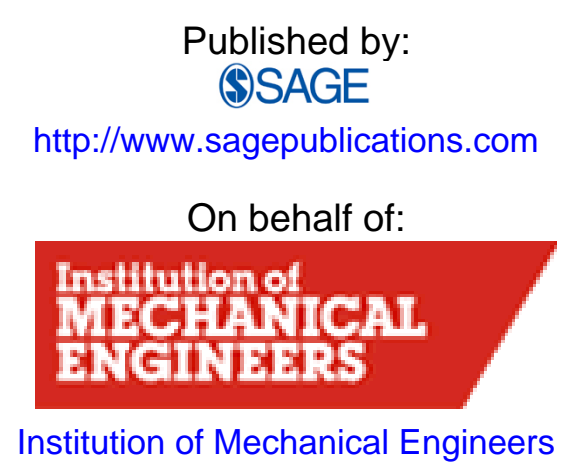

Additional services and information for Proceedings of the Institution of Mechanical Engineers, Part A: Journal of Power and Energy can be found at:

Email Alerts: http://pia.sagepub.com/cgi/alerts

Subscriptions: http://pia.sagepub.com/subscriptions

Reprints: http://www.sagepub.com/journalsReprints.nav

Permissions: http://www.sagepub.com/journalsPermissions.nav

Citations: http://pia.sagepub.com/content/224/5/629.refs.html

>> Version of Record - Aug 1, 2010

What is This? 


\title{
Simulation procedure for the co-optimization of photovoltaic water pumping systems
}

\author{
I Odeh ${ }^{1}$, Y G Yohanis ${ }^{2 *}$, and B Norton ${ }^{3}$ \\ ${ }^{1}$ Sweileh, Amman, Jordan \\ ${ }^{2}$ Centre for Sustainable Technologies, University of Ulster, Newtownabbey, UK \\ ${ }^{3}$ Dublin Energy Laboratory, Dublin Institute of Technology, Dublin, Ireland
}

The manuscript was received on 19 June 2009 and was accepted after revision for publication on 18 February 2010.

DOI: 10.1243/09576509JPE844

\begin{abstract}
Photovoltaic (PV)-powered centrifugal water pumping systems have been modelled based on field experience and analysis of long-term measured performance of several installed PV-powered water pumping systems. This paper presents detailed modelling of a PV array, an inverter, a three-phase induction motor, a centrifugal pump, a well, a storage tank, an overflow controller, and an integrated reverse osmosis desalination unit. The component models were validated using both laboratory measurements and long-term monitored data. All system components have been modelled separately, and the system was modelled in TRNSYS. The models are capable of simulating grid-connected, diesel-powered, and PV-powered water pumping systems, and can consider the following design and operational variables: constant voltage tracking, voltage frequency modulation, and maximum power point tracking algorithms; variable inverter frequency with variable motor efficiency, variable inverter frequency with constant motor efficiency, and constant inverter frequency with variable motor efficiency algorithms; and variation in PV temperature.
\end{abstract}

Keywords: photovoltaic water pumping, TRNSYS, modelling, photovoltaic array, inverter

\section{INTRODUCTION}

The influence of pumping head, insolation, and photovoltaic (PV) array size on the performance of PV water pumping systems and their economic viability have been investigated and reported previously $[\mathbf{1}, 2]$. Abdolzadeh et al. [3] investigated the possibility of improving the performance of a PV water pumping system and have shown that when the operating head is fixed, the calculated array power should not be more than the power of the motor pump at maximum speed, because the array and system efficiencies decrease and the remaining array power is not utilized. The investigation by Vilela and Fraidenraich [4] of the relationship between water pumping capacity, storage tank size, and water demand for a given water deficit has shown that these systems yield iso-deficit lines

\footnotetext{
*Corresponding author: Centre for Sustainable Technologies, School of the Built Environment, University of Ulster, Shore Road, Jordanstown, Newtownabbey, Northern Ireland BT37 OQB, UK. email:yg.yohanis@ulster.ac.uk
}

(curves of equal water deficit) if their critical levels (radiation at which pumping begins). These iso-deficit lines allow the calculation of water pumping systems for meeting specified demands. Similar other design tools $[5,6]$ and a system of design based on experimental work have been proposed $[\mathbf{7}, \mathbf{8}]$. A similar tool that can consider rapid performance variations of a PV pumping system has also been developed [9]. Software programs previously developed for design and simulation of PV-water pumping systems such as WATSUN-PV [10], PVPUMP [11], DASTPVPS $[\mathbf{1 2}, \mathbf{1 3}$, INSEL [14], and SOLAG [15], in general, have not been validated with adequate experimental data [16]. They also do not provide the daily load profile, the storage capacity, and true mismatch losses [17].

A 'practical' model may be defined as using input data easily acquired from standard manufacturers' data sheets or through simple laboratory tests, whereas a 'good' model predicts outputs to within the error associated with their experimental measurement when both use the same input data. To achieve the accuracy of the latter with the simplicity of the former, a model has been developed and validated 


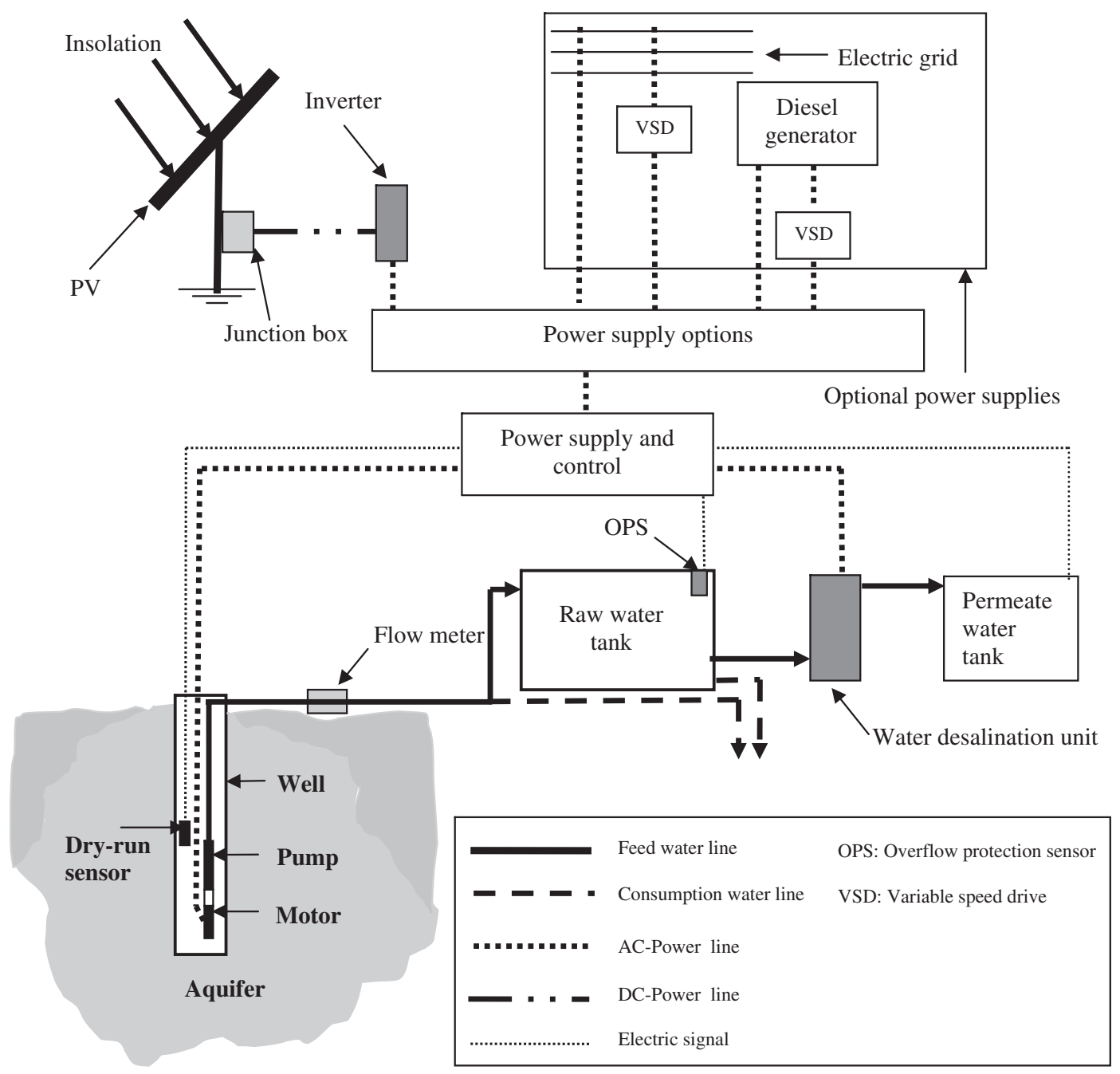

Fig. 1 System components and power supply options

using both laboratory measurements and long-term field data. In addition to the PV pumping system, the model includes a water storage tank and an overflow protection device to enable the investigations of the effect of the mismatch of water demand and supply patterns and system over-sizing owing to site requirements and type of consumers. The model also includes a basic reverse osmosis desalination system to utilize unused PV power.

\section{SYSTEM MODELLED}

The system considered in the study consists of the following:

(a) a power supply;

(b) a direct current (DC)/alternating current (AC) inverter;

(c) an AC induction motor;

(d) a centrifugal pump;

(e) a well; (f) a water storage tank;

(g) an overflow protection device;

(h) a water desalination system.

as shown in Fig. 1. Each component has been modelled separately and interconnected with other components of the system via a series of inputs and outputs. The model simulates water pumping and water desalination systems powered by PV via a DC/AC inverter. Based on the DC control algorithm of the inverter used, the model simulates constant voltage tracking, voltage frequency modulation, and maximum power point tracking (MPPT). For the AC control algorithm of the inverter used, the model simulates the following: variable inverter frequency with variable motor efficiency, variable inverter frequency with constant motor efficiency, and constant inverter frequency with variable motor efficiency. The model also simulates grid-connected and diesel-powered water pumping and water desalination systems. Systems coupled with a variable speed drive can also be simulated. 


\section{SYSTEM MODELLING}

TRNSYS [18] was selected to:

(a) enable all simulation options to be undertaken;

(b) consider transient and steady-state conditions;

(c) to easily update the simulation program for any further system development.

A TRNSYS component (submodel) consists of fixed parameters, variable inputs (which may be outputs of other components), and outputs. The submodels or components are referred to as types. A system is structured using a set of components interconnected in such a manner to execute a specific task. A deck file is prepared by the user, in which all the parameters of components are entered and controlled during the simulation.

Type 94 is a PV array submodel, which includes a new correlation for PV temperature and is also capable of simulating different types of inverter algorithms. Type 101 is a water pumping submodel, Type 103 is a water storage tank submodel, and Type 104 is a water desalination unit submodel. The remaining models are standard TRNSYS components used for data input, radiation data processing, and printing. Using these types, a new system model has been developed to simulate a PV-powered water pumping system. In total, the model has 44 parameters and 19 inputs and 65 outputs.

\section{DESCRIPTION OF COMPONENTS AND THEIR MODELLING}

\subsection{PV array}

The PV array component, Type 94, provided in the TRNSYS library, models the PV power output using the parameters of the PV module. Type 16, the Radiation Processor component, was used to process insolation data on a horizontal plane into beam, diffuse, and in-plane (i.e. inclined plane) insolation. When inplane insolation data are available, it can be used directly by Component Type 94 . Ambient temperature and in-plane insolation data are used to predict cell temperature. Based on module characteristics, number of modules used in parallel and series, and type of inverter used in the system, Component Type 94 gives voltage, current, maximum power point voltage, maximum power point current, open circuit voltage, short-circuit current, and cell temperature outputs. Parameters, inputs, and outputs of this component are shown in Table 1 [18].

A new correlation for cell temperature (equation (1)) was obtained on the basis of long-term field data [19]. This correlation has been used as an alternative to that

Table 1 Parameters, inputs, and outputs of PV array component (Type 94)

Parameters Module short-circuit current at reference conditions (A)

Module open-circuit voltage at reference conditions (V) Reference temperature (usually $298 \mathrm{~K}$ )

Reference insolation (usually $1000 \mathrm{~W} / \mathrm{m}^{2}$ )

Module voltage at maximum power point at reference conditions (V)

Module current at maximum power point, reference conditions (A)

Temperature coefficient of short-circuit current, reference conditions (A/K)

Temperature coefficient of open-circuit voltage, reference conditions $(\mathrm{V} / \mathrm{K})$

Number of cells wired in series in module

Number of modules in series in array

Number of modules in parallel in array

Inputs

Total incident insolation on inclined plane $\left(\mathrm{kJ} / \mathrm{m}^{2} / \mathrm{h}\right)$

Ambient temperature $\left({ }^{\circ} \mathrm{C}\right)$

Load voltage $(\mathrm{V})$

Flag for convergence in direct-coupled systems: 0 to disable or $\neq 0$ to activate algorithm

Slope of PV array (degrees)

Output Array voltage (V)

Array current (A)

Power at voltage tracking operation (W)

Power at maximum point along power-voltage curve (W)

Fraction of maximum power utilized (no MPPT)

Voltage at maximum power point $(\mathrm{V})$
Insolation at nominal operating cell temperature (NOCT) $\left(\mathrm{W} / \mathrm{m}^{2}\right)$

Individual module area $\left(\mathrm{m}^{2}\right)$

$\tau \alpha$ at normal incidence; $>0$, given value used for all angles of incidence; $<0$, use given for normal incidence and incidence angle modifier correlation will be used for all other angles

Semiconductor band gap (1.12 eV for silicon PV modules)

Module series resistance: $>0, R_{s}$ known value; $<0, R_{s}$ to be calculated

Slope of $I-V$ curve at short circuit; $<0,5$-parameter, thin film model; >0, 4-parameter single/polycrystalline model (A/V)

Parameter referring to DC side; 1 for constant voltage tracking; 2 for voltage frequency modulation

Minimum inverter voltage for $V=V_{0}+V_{1} f(V)$

First-order coefficient for $V=V_{0}+V_{1} f\left(V \mathrm{~Hz}^{-1}\right)$

Ambient temperature at NOCT $(\mathrm{K})$

Module temperature at NOCT (K)

Beam insolation $\left(\mathrm{kJ} / \mathrm{m}^{2} / \mathrm{h}\right)$

Diffuse insolation $\left(\mathrm{kJ} / \mathrm{m}^{2} / \mathrm{h}\right)$

Angle of incidence for beam insolation (degrees)

System frequency $(\mathrm{Hz})$

Current at maximum power point (A)

Open-circuit voltage (V)

Short-circuit current (A)

Array fill factor

Cell temperature (K) 
implemented in Component Type 94 in TRNSYS

$$
T_{\mathrm{C}}=0.988 T_{\mathrm{a}}+0.02778 I-1.18
$$

\subsection{Inverter}

Inverters convert DC power produced by the PV array into AC power fed to the motor. In terms of power control in the DC side of the inverter, three different types of voltage-source inverters, dominant in PV water pumping, are available: MPPT inverters, constant voltage tracking inverters, and voltage/frequency modulation inverters. In MPPT inverters, a searching methodology is implemented electronically, in which DC and DC-voltage values are sensed and PV power is calculated. The power resulting from a certain search step is compared with other power values resulting from other steps, and the highest value is selected as the maximum power point. This search methodology is a continuous loop as input parameters (insolation and ambient temperature) vary over the course of the day. In constant voltage tracking inverters, the working principle is simpler than that of the MPPT inverters. The PV array is operated at a fixed voltage corresponding normally to the average range of the MPP voltage values, without considering the effects of insolation and temperature on the maximum power point location on the PV array $I-V$ curve. In voltage/frequency modulation inverters, the DC voltage of the PV array is controlled by the inverter based on the output frequency value, considering constant voltage/frequency algorithm. The user can set certain parameters in the site [20].

Algorithms for all three inverter types were included in the Water Pumping Subsystem component, Type 101, and the PV Array component, Type 94. As shown in Fig. 2, the user can select an inverter simulation algorithm; if parameter number 14 ('INVTYPE' in Component Type 101) is set to 1 , then MPPT inverter algorithm is used in the simulation; if set to 2 , then voltage tracking algorithm is used. Two algorithms for voltage tracking inverters can be applied. One is for constant voltage tracking inverters and the other is for voltage/frequency modulation inverters. The following three parameters were added to the standard Type 94 component to simulate constant voltage tracking and voltage/frequency modulation algorithms: INVMODE, which is used to indicate the voltage tracking algorithm applied in the system, such that INVMODE $=1$ is for constant voltage tracking and INVMODE $=2$ is for voltage/frequency modulation; and coefficients $V_{0}$ and $V_{1}$ for equation (2). The voltage in voltage/frequency modulation inverters is defined as follows [20]

$$
V_{\mathrm{inv}}=V_{0}+V_{\mathrm{l}} f
$$

where $V_{0}$ and $V_{1}$ are constants and $f$ is the working frequency of the system. Typically, these inverters are of parameterized type, where the user can set the parameters $V_{0}$ and $V_{1}$ in the field. Pump frequency, an output from Component Type 101, is used as input to Component Type 94 to determine inverter voltage as defined by equation (2).

Normalized power is calculated as the ratio between measured output power and nominal inverter power. Laboratory test results of inverter efficiency as a function of normalized power for two inverters by Baumeister et al. [13] have shown that inverter efficiency is low at low input power and then increases up to a certain limit beyond which it remains constant (Fig. 3). In PV water pumping, the operating region where input power is too low is insignificant

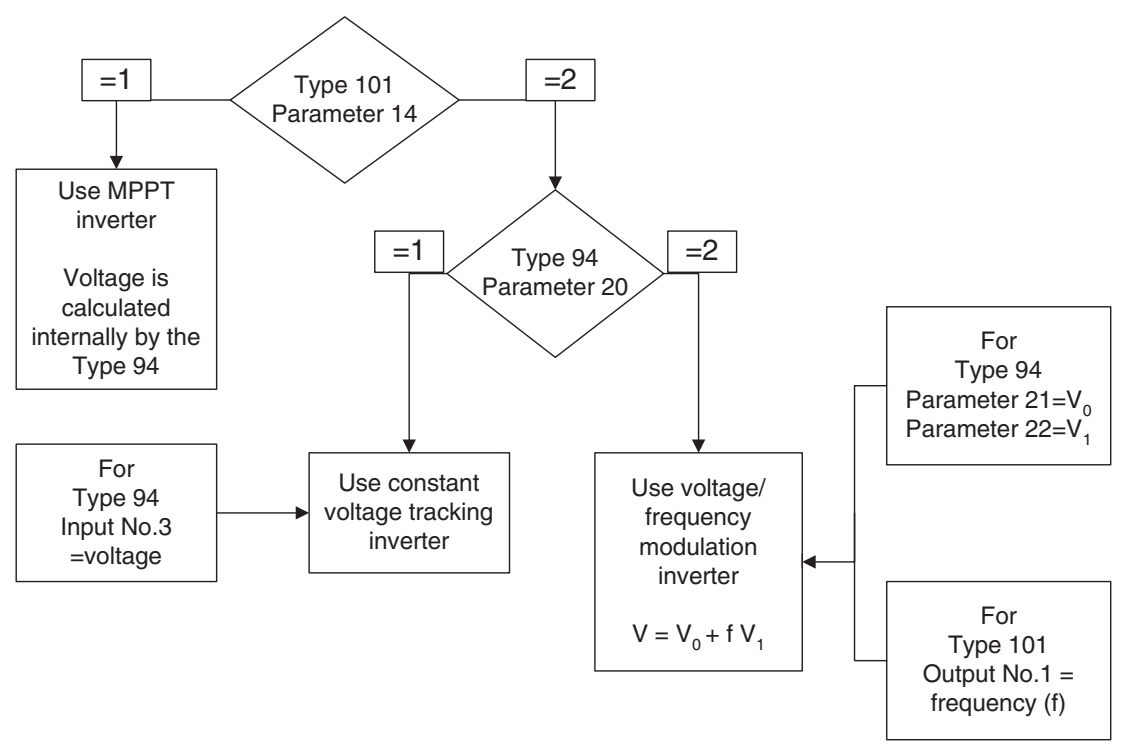

Fig. 2 Flowchart for inverter simulation algorithms 


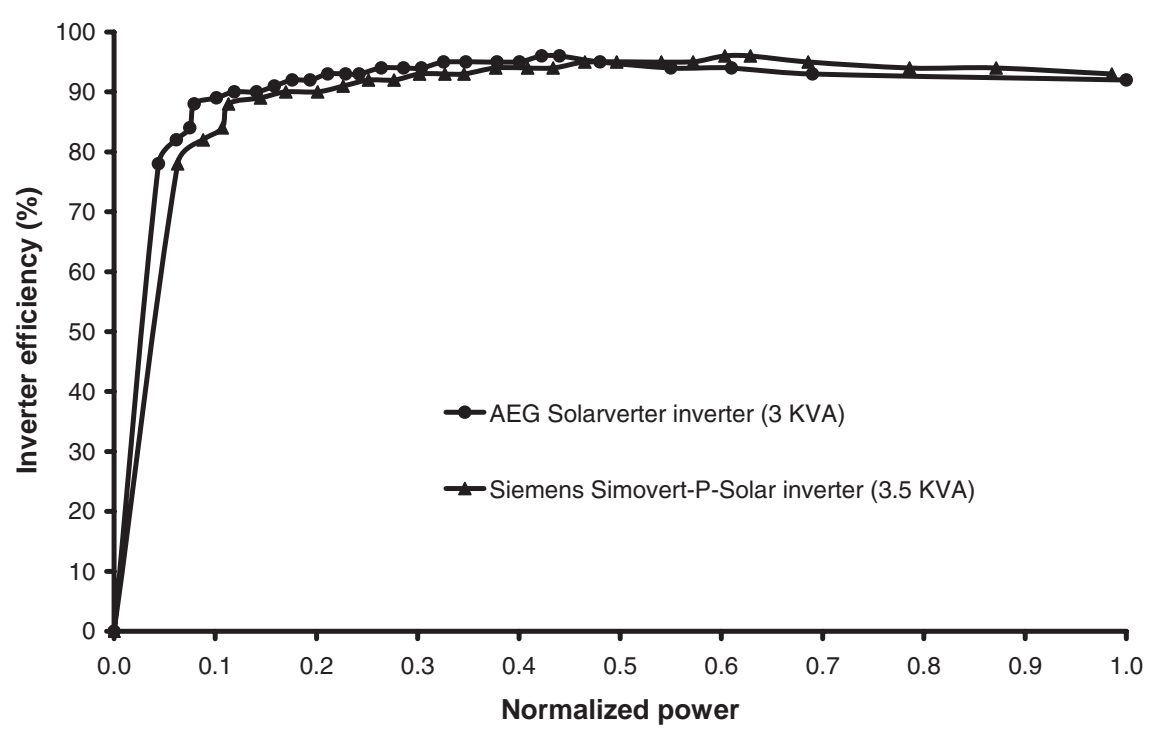

Fig. 3 Inverter efficiency as a function of normalized power [6]

as the system requires a threshold power to start delivering water to the surface. The user can usually set a lowest frequency at which the inverter switches off automatically $[\mathbf{2 0}, \mathbf{2 1}]$ in order to increase the inverter lifetime. However, inverter efficiency is considered constant over the operating range in this work. In Component Type 101, inverter efficiency is given as parameter number 10. Considering that $\mathrm{PV}$ power is determined by Component Type 94, inverter output power is therefore determined by

$$
P_{\text {inv }}=\eta_{\text {inv }} P_{\mathrm{pv}}
$$

Parameters, inputs, and outputs of this component (Type 101) are shown in Table 2. Most inverters used in PV water pumping are equipped with a controller in the AC side to increase motor efficiency at part-load conditions.

\subsection{Motors}

Stator and rotor ohmic resistance, stator and rotor leakage reactance, magnetizing reactance, and iron and friction losses are neither available in the standard manufacturers' data sheets nor readily obtained experimentally. Manufacturers' performance curves were therefore used to model the motors. The model was developed to simulate constant or variable motor efficiency and different power supply algorithms. A parameter referred to as 'power supply' is used in Component Type 101 to refer to the power supply used. Constant motor efficiency was assumed and parameter number 16 is set to 1.0 when, as shown in Fig. 4, the following conditions apply:

(a) the system is supplied directly from the electric grid; (b) the system is supplied directly from a diesel generator;

(c) a variable speed drive that leads to almost constant motor efficiency is connected between the system and the power supply (electric grid or diesel generator);

(d) a DC/AC inverter equipped with $V / f$ controller that leads to constant motor efficiency is connected between the motor-pump set and a PV array.

Variable motor efficiency was assumed and parameter number 16 is set to 2.0 when (Fig. 4):

(a) a variable speed drive that leads to variable motor efficiency is connected between the motor-pump set and the power supply (electric grid or diesel generator);

(b) a DC/AC inverter equipped with $V / f$ controller that leads to variable motor efficiency is connected between the motor-pump set and a PV array.

Medium- and large-scale PV water pumping systems use submersible centrifugal pumps with commonly three-phase AC motors and DC/AC inverters. For this configuration:

(a) a wide range of pumps are available in the market that can match demand quantity and well characteristics;

(b) good overall system efficiency can be achieved;

(c) inverters of different sizes are available;

(d) durable and reliable motors and pumps can be used.

In DC systems, most available DC motors are equipped with carbon brushes for commutation of the direct current, which have to be replaced regularly, 
Table 2 Parameters, inputs, and outputs for water pumping system component (Type 101)

Parameters Well static head (m)

Second-order coefficient of head-flowrate,

$H=h_{\mathrm{st}}+C_{4} Q^{2}\left(\mathrm{~s}^{2} / \mathrm{m}^{5}\right)$

Reference frequency at which head-flow and efficiency-flow

data files are given $(\mathrm{Hz})$

Maximum system frequency $(\mathrm{Hz})$

Shaft power at shut off condition at reference speed (W)

Nominal design flowrate of the pump $\left(\mathrm{m}^{3} / \mathrm{h}\right)$

Total area of PV array $\left(\mathrm{m}^{2}\right)$

Motor efficiency at maximum system frequency (\%)

Inputs $\quad$ Motor efficiency at rated power (\%)

Rated motor input power (W)

Motor output power (only when extern) (W)

Inverter output power (only when extern) (W)

Outputs
Pump speed (Hz)

Motor output power (W)

Pump flowrate $\left(\mathrm{m}^{3} / \mathrm{h}\right)$

Total pumping head (m)

Pump efficiency (\%)

Hydraulic power (W)

Mechanical motor power used by the pump (W)

Error and/or warning messages $(0,1,2,3,4)$

Zero-order coefficient for $H=A_{0}+A_{2} Q^{2}$ (m)

Second-order coefficient of $H=A_{0}+A_{2} Q^{2}\left(\mathrm{~s}^{2} / \mathrm{m}^{5}\right)$

Shaft power, shut off at reference speed (W)

Motor output power when maximum frequency is exceeded (W)

Inverter output power when maximum frequency is exceeded (W)

PV power when maximum frequency is exceeded (W)

Subsystem efficiency, maximum frequency exceeded (\%)

Inverter output power (W)

Subsystem efficiency (\%)

Motor efficiency (\%)

Motor efficiency, maximum frequency exceeded (\%)
Water storage tank size $\left(\mathrm{m}^{3}\right)$

Inverter efficiency

Zero-order coefficient for motor, $P_{\mathrm{m}-\text { out }}=f\left(P_{\text {inv }}\right)(\mathrm{W})$

First-order coefficient for motor equation

$P_{\mathrm{m}-\text { out }}=f\left(P_{\text {inv }}\right)$

Second-order coefficient for motor equation,

$P_{\mathrm{m}-\mathrm{out}}=f\left(P_{\mathrm{INV}}\right)\left(\mathrm{W}^{-1}\right)$

Inverter type $(1=\mathrm{MPPT}, 2=\mathrm{VT})$

A compensation factor for PV losses

Power supply: $1=$ grid and diesel (constant motor efficiency), $2=\mathrm{PV}$ (variable motor efficiency)

Maximum PV power (output 4) of Type 94 (W)

In-plane insolation (output 7), Type $16\left(\mathrm{~kJ} / \mathrm{m}^{2} / \mathrm{h}\right.$ )

Water volume in tank (output 1) of Type $103\left(\mathrm{~m}^{3}\right)$

Voltage tracking power (output 3) of Type 94 (W)

PV efficiency (\%)

System efficiency (\%)

Motor power when grid is used (W)

Zero-order coefficient for $E_{\mathrm{P}}=f(Q)(\%)$

First-order coefficient for $E_{\mathrm{P}}=f(Q)\left(\% \mathrm{~s} / \mathrm{m}^{3}\right)$

Second-order coefficient for $E_{\mathrm{P}}=f(Q)\left(\% \mathrm{~s}^{2} / \mathrm{m}^{6}\right)$

Third-order coefficient for $E_{\mathrm{P}}=f(Q)\left(\% \mathrm{~s}^{3} / \mathrm{m}^{9}\right)$

PV power (W)

Power required to start water delivery (W)

Water volume in the tank $\left(\mathrm{m}^{3}\right)$

Surplus PV power when $N_{\text {MAX }}$ is reached (W)

Unused PV power when tank is full (W)

Un-pumped water flowrate for full tank $\left(\mathrm{m}^{3} / \mathrm{h}\right)$

Accumulated $P_{\text {NMAX }}(\mathrm{MJ})$

Accumulated $P_{\text {LOSS }}(\mathrm{MJ})$

PV output power that is used by the inverter (W)

Accumulated QLOSS $\left(\mathrm{m}^{3}\right)$

In-plane insolation $\left(\mathrm{W} / \mathrm{m}^{2}\right)$

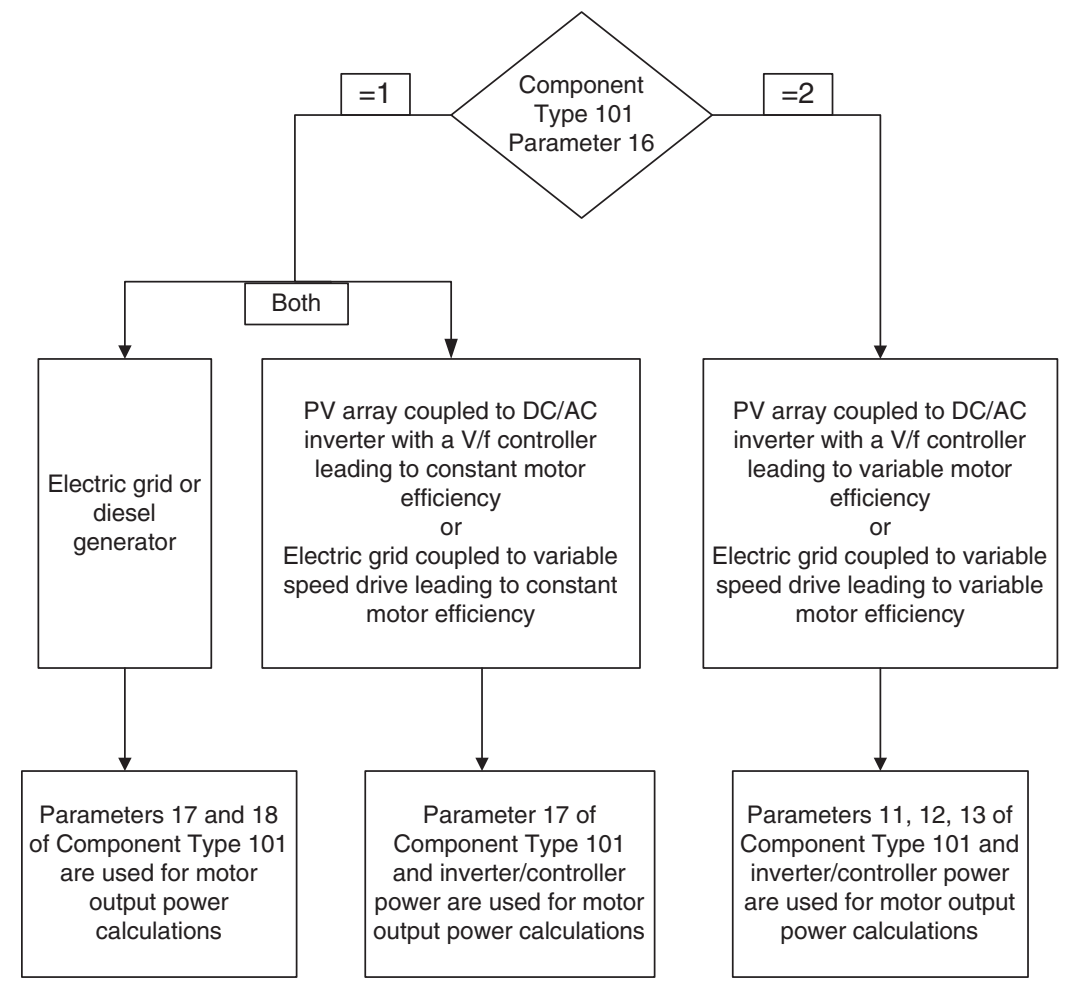

Fig. 4 Power supply selection procedure and corresponding simulation algorithm 
thereby increasing operating cost and decreasing system reliability $[\mathbf{2 2}, \mathbf{2 3}$. The advantage of brushless DC motors that have been introduced as an alternative to conventional motors is that no replacement of wearing parts is necessary; the electronic commutator (similar to an inverter) is integral to the motor. The disadvantages of brushless motors include high cost, few manufacturers, and limited range of sizes [22].

Depending on whether power is supplied by the electric grid, a diesel generator, or a PV array and considering the control algorithm equipped in the inverter, the following different algorithms are available in the model.

1. The first algorithm assumes constant motor efficiency. It is applied when using inverters equipped with $V / f$ controllers are capable of maintaining constant motor efficiency over the operating range of the systems $[\mathbf{2 4 , 2 5 ]}$. It is also applied when constant power is supplied from the electric grid or a diesel generator. The value of this efficiency can be obtained from manufacturers' data sheets and is given as parameter number $17\left(\eta_{\mathrm{m}}\right)$ in Component Type 101. Given inverter power (motor input power, $P_{\mathrm{m} \text {-inp }}$ ) from equation (3), motor power is calculated as follows

$$
P_{\mathrm{m}-\mathrm{out}}=\eta_{m} P_{\mathrm{m}-\mathrm{inp}}
$$

when the grid or a diesel generator is used, input motor power can be assumed to be constant. Rated motor input power is given as parameter number 18 of Component Type 101 and used in equation (4) to determine motor output power.

2. The second algorithm uses a parabolic correlation for motor output as a function of motor input. This algorithm is applied when the power supply does not lead to constant efficiency operation. As can be seen in Fig. 5, laboratory tests and manufacturers' data sheets indicate that a second-order polynomial (equation (5)) is sufficiently accurate to represent the relationship between output motor power and input motor power. The coefficients of the equation are used as parameters for Component Type 101 as follows: $m_{\mathrm{o}}$ is the zero-order coefficient, $m_{1}$ is the first-order coefficient, and $\mathrm{m}_{2}$ is the second-order coefficient. It is also shown in Fig. 5 that manufacturers' data are well matched with laboratory measurements [21]. Either manufacturers' data or laboratory measurements can be used to determine parameters $m_{0}, m_{1}$, and $m_{2}$ using the following equation

$$
P_{\mathrm{m}-\mathrm{out}}=m_{0}+m_{1} P_{\mathrm{m}-\mathrm{inp}}+m_{2} P_{\mathrm{m}-\mathrm{inp}}^{2}
$$

3. The third algorithm assumes constant frequency and variable motor efficiency. This algorithm is applied when standard inverters are used in the system. These types of inverters are not recommended in PV water pumping applications. However, the algorithm applied in the model is the same as that used in the second algorithm. The equation of output power as a function of input power can be obtained by processing manufacturers' performance curves provided in data sheets at standard frequency. Parameters, inputs, and outputs of the motor are included in Component Type 101as shown in Table 2.

\subsection{Pumps}

The pump characteristics are defined as the variation of the pumping head with flowrate at constant pump speed. Standard manufacturers' data sheets include the head-flowrate curve at nominal operating speed,

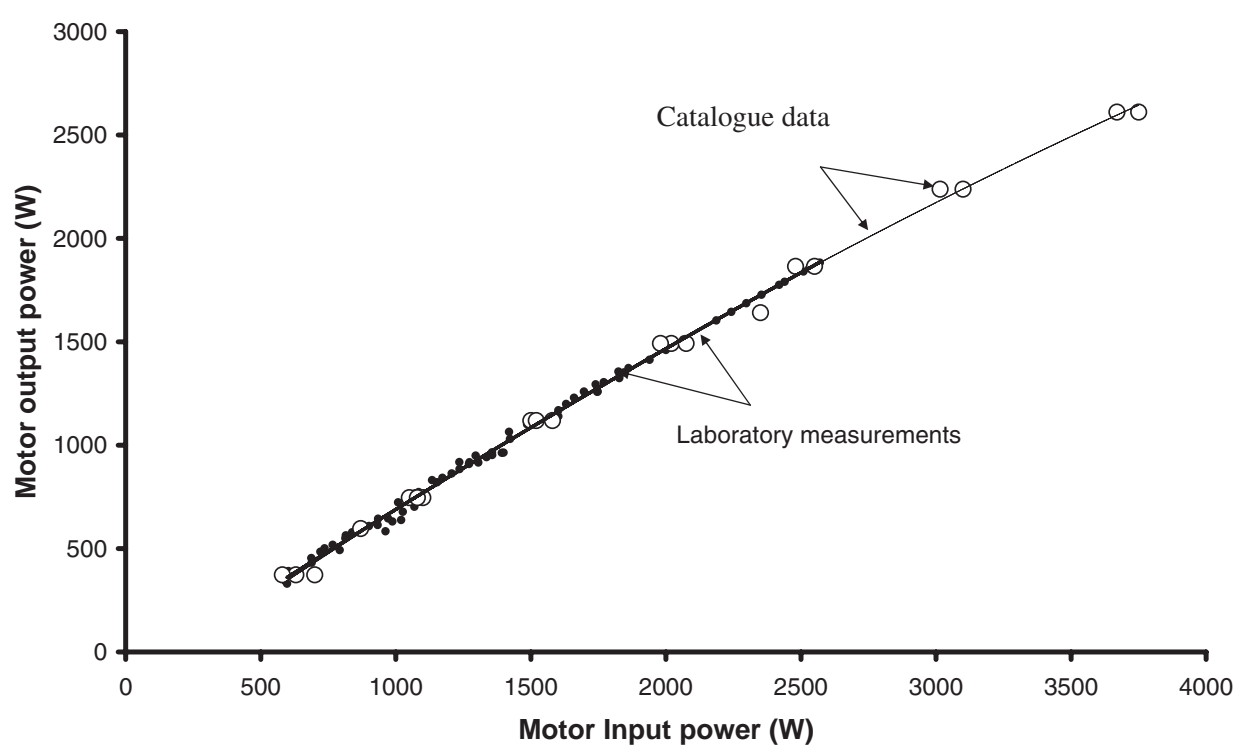

Fig. 5 Motor output and input power for variable frequencies (measured and laboratory data) 
which normally corresponds to the electric grid frequency. PV water pumping systems operate at variable pump speeds with diurnal variation of insolation. A multi-stage centrifugal pump, the normal pump type used in deep well water pumping applications, operates at high efficiency for a limited range of pump speeds and pumping heads. Typical values at nominal speed are in the range of 60-70 per cent [26]. As values very different from the actual nominal pumping head reduce a pump's efficiency, head-flowrate curves were defined for the whole working speed range.

\subsection{Well system}

The total well system head consists of three components: static head, friction head in the piping system, and well drawdown head. It can be written as follows

$$
h=h_{\mathrm{st}}+h_{\mathrm{f}}+h_{\mathrm{d}}
$$

Well static head can be determined by measuring the water level in the well at no flow conditions. Friction and drawdown heads can be determined either theoretically or experimentally. The Darcy-Weisbach equation combined with the supplementary Moody diagram [27] gives friction losses in the water pipe. The form of the equation used widely is

$$
h_{\mathrm{f}}=\frac{f_{\mathrm{d}} L_{\mathrm{p}}}{D_{\mathrm{p}}} \frac{V_{\mathrm{W}}^{2}}{2 g}
$$

For all fittings, e.g. elbows, valves, and flow meters, friction losses are defined as an equivalent value of $L_{\mathrm{p}} / D_{\mathrm{p}}$ for a straight pipe. Equation (7) can be rewritten as follows

$$
h_{\mathrm{f}}=\frac{V_{\mathrm{W}}^{2}}{2 g} \sum \frac{f_{\mathrm{d}} L_{\mathrm{p}}}{D_{\mathrm{p}}}
$$

where $\sum f_{\mathrm{d}} L_{\mathrm{p}} / D_{\mathrm{p}}$ can be determined from manufacturers' literature.

Velocity, $V_{\mathrm{W}}$, can be expressed in terms of flowrate as follows

$$
V_{\mathrm{W}}=\frac{Q}{A_{\mathrm{p}}}
$$

Substituting for $V_{\mathrm{w}}$ from equation (9) into equation (8), the latter becomes

$$
h_{\mathrm{f}}=Q^{2} \frac{1}{2 g A_{\mathrm{p}}^{2}} \sum \frac{f_{\mathrm{d}} L_{\mathrm{p}}}{D_{\mathrm{p}}}
$$

The Darcy friction factor, $f_{\mathrm{d}}$, can be found from Moody diagram [27].

From equations (5) and (10), the pumping head required to overcome the static head and friction losses can be written as follows [28-30]

$$
h_{\mathrm{s}-\mathrm{f}}=h_{\mathrm{st}}+F Q^{2}
$$

where $F$ is defined as follows

$$
F=\frac{1}{2 g A_{\mathrm{p}}^{2}} \sum \frac{f_{\mathrm{d}} L_{\mathrm{p}}}{D_{\mathrm{p}}}
$$

Well drawdown is defined as the difference between the water level during pumping and the initial static water level. Well drawdown, caused primarily by loss of head in the aquifer and loss of head in the well itself, is measured usually as the difference between the dynamic and the static water levels during pumping. In this work, static and dynamic heads were determined experimentally, and thus the total system well head is defined as

$$
h=h_{\mathrm{st}}+C_{4} Q^{2}
$$

Static head $h_{\mathrm{st}}$ and coefficient $C_{4}$ are used by the model for parameters 1 and 2, respectively, in Component Type 101.

\subsubsection{Combination of pump and well system characteristics}

At any point during the course of the day, the headflow curve of the system should intersect with one of the head-flow curves of the pump as shown in Fig. 6. Equation (13) can be rewritten as follows

$$
A_{0-1}\left[\frac{N_{2}}{N_{1}}\right]^{2}+A_{2-1} Q_{2}^{2}-h_{\mathrm{st}}-C_{4} Q_{2}^{2}=0
$$

The following relationship can also be written as

$$
\begin{gathered}
E_{0-1}+E_{1-1} \frac{N_{1}}{N_{2}} Q_{2}+E_{2-1} \frac{N_{1}^{2}}{N_{2}^{2}} Q_{2}^{2}+E_{3-1} \frac{N_{1}^{3}}{N_{2}^{3}} Q_{2}^{3} \\
-\left\{\frac{\rho g Q_{2}\left[A_{0-1}\left(N_{2} / N_{1}\right)^{2}+A_{2-1} Q_{2}^{2}\right]}{P_{\text {m-out }, 2}}\right\}=0
\end{gathered}
$$

Equations (14) and (15) are solved numerically in Component Type 103 to give pump speeds and flowrates by means of Newton's method [20, 31].

\subsection{Water storage tank and overflow protection device}

The Water Storage Tank component, Type 103, is developed to simulate a storage tank equipped with an overflow protection device. The size of the storage tank and the threshold minimum water limit are used as parameters in Component Type 103. An hourly water demand profile is given in the model as a separate data file. When the storage tank is full, the simulated overflow protection device instructs Component Type 


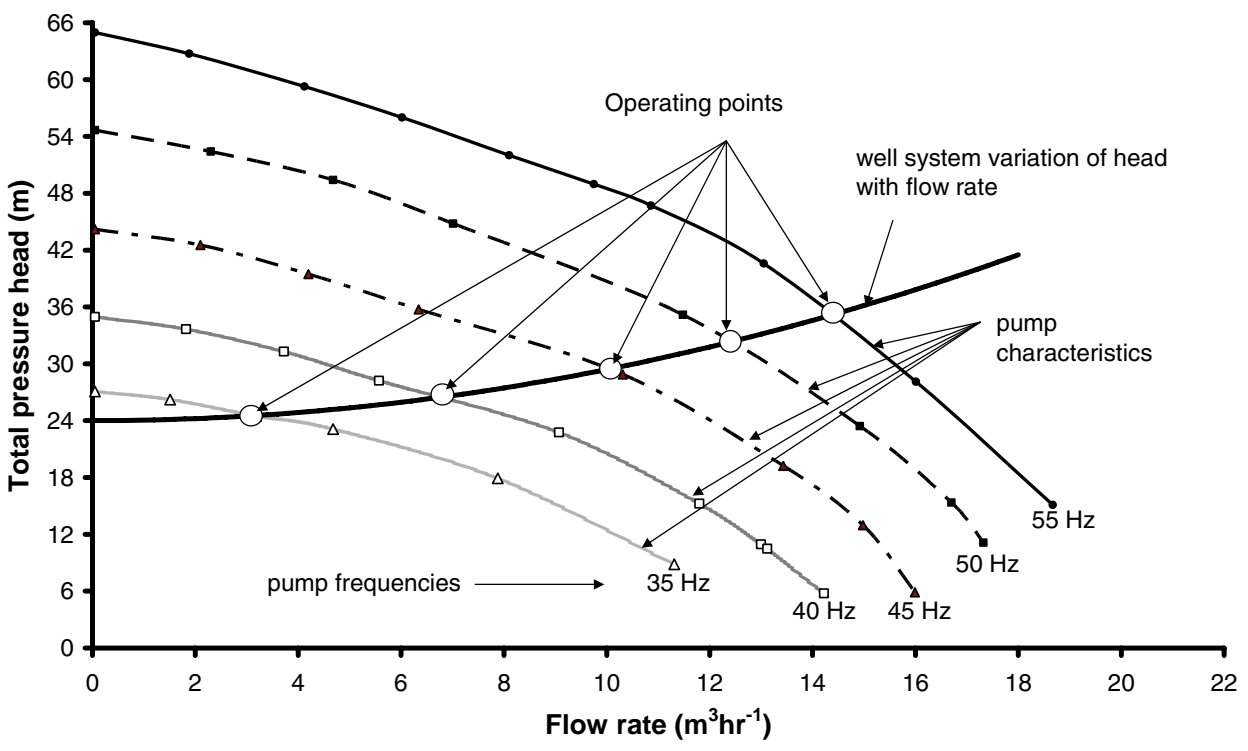

Fig. 6 Work points of pump and well system characteristics

Table 3 Parameters, inputs, and outputs for water storage tank component (Type 103)

\begin{tabular}{ll}
\hline Parameters & $\begin{array}{l}\text { Storage tank maximum capacity }\left(\mathrm{m}^{3}\right) \\
\text { Lowest permitted storage capacity in the tank } \\
\text { (threshold) }\left(\mathrm{m}^{3}\right)\end{array}$ \\
Inputs & $\begin{array}{l}\text { Water flowrate of the pump entering the storage } \\
\text { tank }\left(\mathrm{m}^{3} / \mathrm{h}\right)\end{array}$ \\
& Water flowrate used by the demand side $\left(\mathrm{m}^{3} / \mathrm{h}\right)$ \\
Outputs & $\begin{array}{l}\text { Hourly water volume status in the tank }\left(\mathrm{m}^{3}\right) \\
\text { Potential surplus water flowrate when the tank is } \\
\text { full }\left(\mathrm{m}^{3} / \mathrm{h}\right) \\
\\
\text { Deficit water flowrate }\left(\mathrm{m}^{3} / \mathrm{h}\right) \\
\text { Accumulated surplus water volume }\left(\mathrm{m}^{3}\right) \\
\text { Accumulated water deficit volume }\left(\mathrm{m}^{3}\right)\end{array}$ \\
&
\end{tabular}

101 to turn off the pump. Predicted surplus water flowrate and the accumulated water volume during the shut off period are determined by Component Type 103, assuming infinite storage capacity. When the predefined threshold limit of water in the tank is reached, no water will be delivered to the demand side. Water demanded at such times is considered as deficit. Component Type 103 calculates instantaneous water volume in the tank, instantaneous deficit, accumulated deficit, instantaneous surplus, and accumulated surplus. The parameters, inputs, and outputs of Component Type 103 are shown in Table 3.

\subsection{Water desalination system}

A water desalination unit may use surplus solar PV energy when the pumping system is turned off because the storage tank is full (i.e. all the PV power is then available for other uses) and when the pump maximum speed is exceeded (i.e. surplus unused PV power is then available for other uses). The Water
Desalination Unit component, Type 104, is developed to simulate a water desalination system considering a defined value for energy requirement (per cubic metre of permeate). Multiplying surplus/unused energy (concluded from Component Type 101 'Water Pumping Subsystem') by the energy requirement value (taken from desalination unit manufacturers' data sheets) results in permeate output quantity. However, the aim of this work is not to model a water desalination system, but just to give a general indication for the feasibility of using a reverse osmosis desalination unit to utilize the surplus unused energy by the water pumping system in desalinating water. Type 104 calculates instantaneous and accumulated permeate and brine water. The component may be used with a constant power source such as an electric grid or a variable power source such as a PV array. It can also be used in conjunction with a PV water pumping system, in which it uses the full PV power when the storage tank of the pumping system is full and the surplus power when the maximum pump speed is exceeded. The unutilized PV power by the water pumping system, the predicted corresponding un-pumped water quantities when the system is shut off (i.e. when the storage tank is full), and the surplus unused PV power when the pump exceeds its maximum speed are determined by Component Type 101. The parameters, inputs, and outputs, respectively, for Type 104 are shown in Table 4.

\section{DATA FILES REQUIRED}

The user can enter the data files relevant to a specific location. The data files required by the system model described below are summarized in Fig. 7 as follows. 
Table 4 Parameters, inputs, and outputs for water desalination unit component (Type 104)

\begin{tabular}{|c|c|}
\hline Parameters & $\begin{array}{l}\text { Recovery ratio }(\%) \\
\text { Energy consumption per cubic metre of } \\
\quad \text { permeate }\left(\mathrm{MJ} / \mathrm{m}^{3}\right)\end{array}$ \\
\hline Inputs & $\begin{array}{l}\text { Surplus part of PV power not used by the system } \\
\text { when maximum speed of pump is exceeded (W) } \\
\text { PV power not used by system when storage tank is } \\
\text { full and pump is turned off (W) }\end{array}$ \\
\hline Outputs & 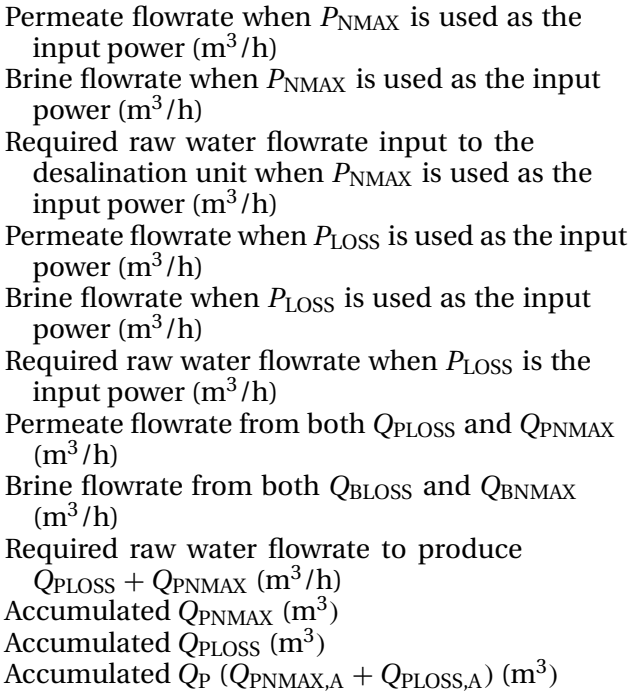 \\
\hline
\end{tabular}

1. Head-flowrate characteristics of the pump at reference speed: Type 101 (Water Pumping Subsystem) requires this file. Data points can be obtained from manufacturers' data sheets or from laboratory tests.

2. Efficiency-flowrate characteristics of the pump at reference speed: this file is required by Type 101 (Water Pumping Subsystem). Data points can be obtained from manufacturers' data sheets or from laboratory tests.

3. Insolation and ambient temperature data: insolation is used as input for Type 16 (Radiation Processor) via Type 9 (Card Reader). Outputs of Type 16 are used as inputs to Type 94 (PV Array). Ambient temperature data are used by Type 94 (PV Array) via Type 9 (Card Reader). Demand data file containing hourly flowrate over the day: it is used as input to Type 103 (Water Storage Tank) via Type 9 (Card Reader). No particular demand profile can be defined in rural applications in which the PV pumping systems were installed or in general application. When two demand profiles having the same volume per day, an $8 \mathrm{~h}$ profile from 08 to $16 \mathrm{~h}$ and a $24 \mathrm{~h}$ profile, were considered for a 1-day autonomy tank and different over-sizing factors, the difference in deficit between the two demand patterns was insignificant at all over-sizing factors [13].

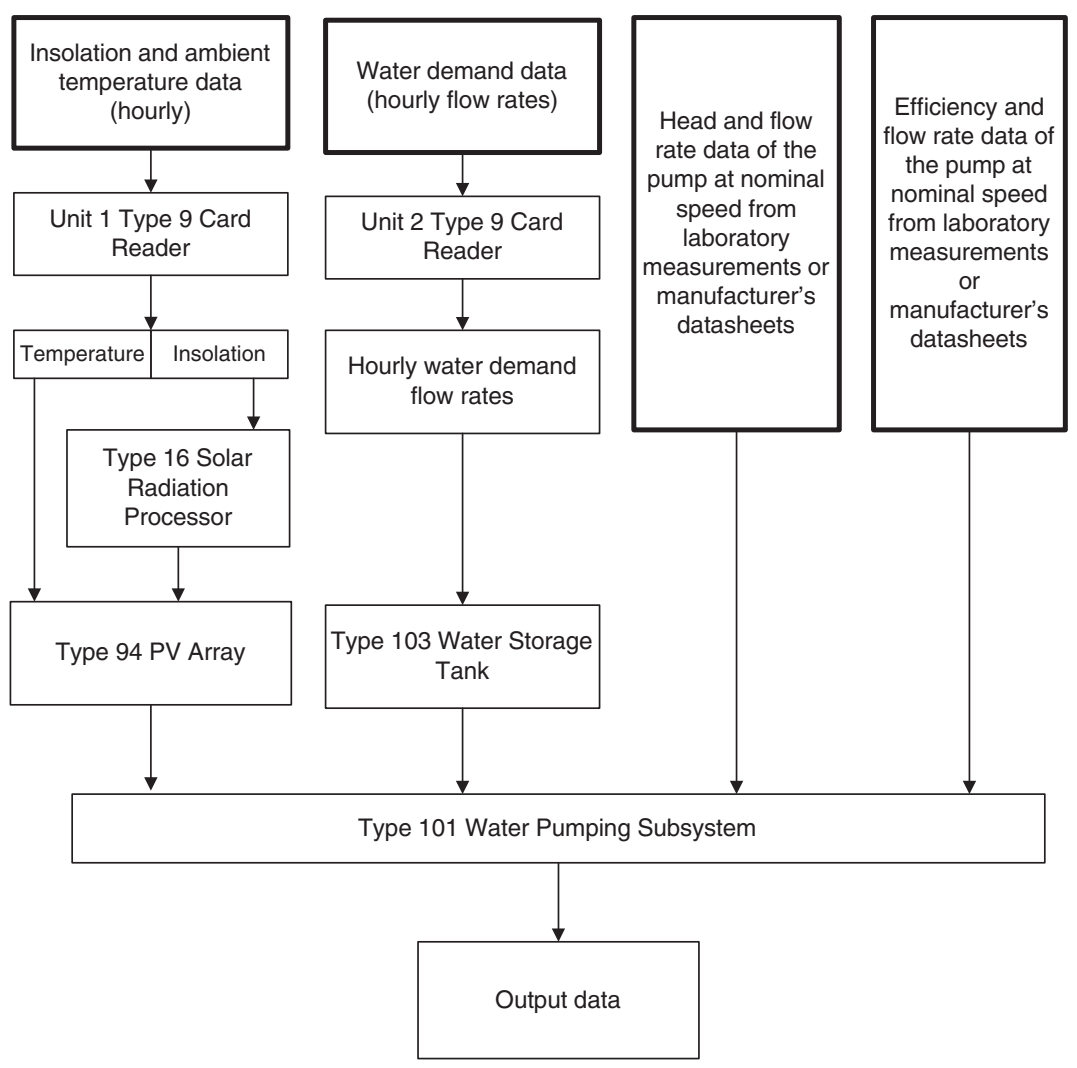

Fig. 7 Data files structure for simulation 
The validation of this model via comparison of predicted performance with long-term field data is reported in a companion paper [32].

\section{CONCLUSIONS}

New TRNSYS models to simulate the water pumping subsystem were developed. The models simulate the following:

(a) grid-connected, diesel-powered, and PV-powered water pumping systems;

(b) constant voltage tracking, voltage frequency modulation, and MPPT algorithms;

(c) variable inverter frequency with variable motor efficiency, variable inverter frequency with constant motor efficiency, and constant inverter frequency with variable motor efficiency algorithms.

A previously developed model for PV array was modified to include a new correlation for PV temperature and to simulate different inverter algorithms. For simplicity, manufacturers' performance curves for motors and pumps can be used for obtaining data required by the model instead of the theoretical motor parameters (implemented in other models) that are neither available in standard manufacturers' data sheets nor readily obtained experimentally.

\section{ACKNOWLEDGEMENTS}

The help and cooperation of the German Agency for Technical Cooperation; Oldenburg University; the Royal Scientific Society, Jordan; the National Energy Research Centre, Jordan; the Water Authority of Jordan; and the Franklin Electric Co. are kindly acknowledged.

(C) Authors 2010

\section{REFERENCES}

1 Odeh, I., Yohanis, Y. G., and Norton, B. Influence of pumping head, insolation and PV array size on PV water pumping system performance. Solar Energy, 2006, 80(1), 51-64.

2 Odeh, I., Yohanis, Y. G., and Norton, B. Economic viability of photovoltaic water pumping systems. Solar Energy, 2006, 80(7), 850-860.

3 Abdolzadeh, M., Ameri, M., and Mehrabian, M. A. The effects of an operating head on the performance of photovoltaic water pumping systems: an experimental investigation. Proc. IMechE, Part A: J. Power and Energy, 2009, 223(A4), 341-347. DOI: 10.1243/09576509JPE693.

4 Vilela, O. C. and Fraidenraich, N. A methodology for the design of photovoltaic water supply systems. Prog. Photovolt. Res. Appl., 2001, 9(5), 349-361.
5 Benghanem, M. and Arab, A. H. Photovoltaic water pumping systems for Algeria. Desalination, 2007, 209(13), 50-57.

6 Martiré, T., Glaize, C., Joubert, C., and Rouvie, B. A simplified but accurate prevision method for along the sun PV pumping systems. Solar Energy, 2008, 82(11), 1009-1020.

7 Kaldellis, J. K., Spyropoulos, G. C., Kavadias, K. A., and Koronaki, I. P. Experimental validation of autonomous PV-based water pumping system optimum sizing. Renew. Energy, 2009, 34(4), 1106-1113.

8 Hamrouni, N., Jraidi, M., and Chérif, A. Theoretical and experimental analysis of the behaviour of a photovoltaic pumping system. Solar Energy, 2009, 83(8), 1335-1344.

9 Fraidenraich, N. and Vilela, O. C. Dynamic behavior of water wells coupled to PV pumping systems. Prog. Photovolt. Res. Appl., 2007, 15(4), 317-330.

10 WATSUN-PV6. A computer program for simulation of solar photovoltaic systems, version 6.1, 1999 (Watsun Simulation Laboratory, University of Waterloo, Ontario, Canada).

11 PVPUMP. Simulation Solarer Pumpensystem manual, version 4, 1993 (Institut fuer Tropentechnologie, Cologne, Germany).

12 Mayer, O., Baumeister, A., and Festl, T. Design, simulation and diagnosis of photovoltaic pumping systems with DASTPVPS. In Proceedings of the 13th European Photovoltaic Solar Energy Conference, Nice, France, 1995, pp. 1915-1917.

13 Baumeister, A., Festl, T., and Mayer, O. DASTPVPS - design and simulation tool for photovoltaic pumping systems, manual, version 5.0, 1993 (Universitat der Bundeswehr, Muenchen, Germany).

14 Scumacher, J. INSEL-handbook, version 5.01, 1997 (University of Oldenburg, Germany).

15 Vilela, O. and Fraidenraich, N. Methodology of analysis of photovoltaic pumping systems, example for a system installed in the Northeast of Brazil. In Proceedings of the 14th European Photovoltaic Solar Energy Conference, Barcelona, Spain, 1997, pp. 2284-2287.

16 Tiba, C. and Barbosa, E. Software for designing, simulating or providing diagnosis of photovoltaic waterpumping systems. Renew. Energy, 2002, 25, 101-113.

17 Arab, A., Chenlo, F., Mukadam, K., and Balenzatequi, J. Performance of PV water pumping systems. Renew. Energy, 1999, 18, 191-204.

18 Betka, A. and Moussi, A. Performance optimization of a photovoltaic induction motor pumping system. Renew. Energy, 2004, 29, 2167-2181.

19 Barlow, R., McNeils, B., and Derrick, A. Solar pumping: an introduction and update on the technology, performance, costs, and economics. World Bank Technical Paper No. 168, Intermediate Technology Publications and the World Bank, Washington DC, USA, 1993.

20 Klein, S. A., Duffie, J. A., Mitchell, J. C., Kummer, J. P., Beckmann, W. A., Duffie, N. A., Braun, J. E., Urban, R. E., Thornton, J. W., Mitchell, J. W., Freeman, T. L., Evans, B. L., and Fiksel, A. TRNSYS 16, Transient Simulation Program. Solar Energy Laboratory, University of Wisconsin-Madison, Wisconsin, USA, 2005.

21 Odeh, I. Modelling, field data analysis and economics of photovoltaic water pumps and the prospects of 
integrating desalination using reverse osmosis. $\mathrm{PhD}$ Thesis, University of Ulster, 2005.

22 Siemens Solar. Sine-wave inverter with microprocessor for standard induction motors, operating instructions manual, 1996 (Siemens Solar, Munich, Germany).

23 Aerovironment. Universal solar pump controller manual, USPC 2000/5000, 2004 (Aerovironment, Monrovia, California, USA).

24 Yao, Y., Baustamente, P., and Ramshaw, R. Improvement of induction motor drive systems supplied by photovoltaic array with frequency control. IEEE Trans. Energy Convers., 1994, 8(1), 47-52.

25 Betka, A. and Moussi, A. Performance optimization of a photovoltaic induction motor pumping system. Renew. Energy, 2004, 29, 2167-2181.

26 KSB. UPA150 submersible motor pumps for well diameters $150 \mathrm{~mm}$ (6 inch) and above, 1990 (KSB, Denmark).

27 Moody, L. Friction factors for pipe flow. ASME Trans., 1944, 66, 671-678.

28 Lasnier, F. and Ang, T. Photovoltaic engineering handbook, 1990 (Asian Institute of Technology, ICP Publishing Limited, Bangkok, Thailand).

29 Eskander, M. and Zaki, A. A maximum efficiency photovoltaic induction motor pump system. Renew. Energy, 1997, 10, 53-60.

30 Betka, A. and Moussi, A. Performance optimization of a photovoltaic induction motor pumping system. Renew. Energy, 2004, 29, 2167-2181.

31 Eckstein, J. Detailed modeling of photovoltaic system components. MSc Thesis, Mechanical Engineering, University of Wisconsin-Madison, Wisconsin, USA, 1990.

32 Odeh, I., Yohanis, Y. G., and Norton, B. Simulation algorithm and validation of a photovoltaic water pumping system model using long-term field data. Proc. IMechE, Part A: J. Power and Energy, 2010, 224(A4), 641-656. DOI: 10.1243/09576509JPE843.

\section{APPENDIX}

\section{Notation}

$A$
$A_{0-1}, A_{2-1}, A_{2}, A_{\mathrm{o}}$
$A_{\mathrm{p}}$
$C_{4}$
$D_{\mathrm{P}}$
$E_{0-1}, E_{1-1}$,
$\quad E_{2-1}, E_{3-1}$
$f \quad$
$f_{\mathrm{d}}$
$F$

current (amperes)

coefficients

cross-sectional area $\left(\mathrm{m}^{2}\right)$

coefficient

pipe diameter $(\mathrm{m})$

coefficients

frequency

Darcy friction factor

defined as equation (12) $g$

$h$

$h_{\mathrm{d}}, h_{\mathrm{f}}, h_{\mathrm{s}-\mathrm{f}}, h_{\mathrm{st}}$

$h_{\mathrm{r}}$

$\mathrm{Hz}$

$I_{\mathrm{n}}, I$

$L_{\mathrm{p}} / D_{\mathrm{p}}$

$m_{0}, m_{1}, m_{2}$

$N_{1}, N_{2}$

$N_{\text {max }}$

$P_{\text {inv }}, P_{\text {m-inp }}$,

$P_{\mathrm{m}-\text { out }}, P_{\mathrm{PV}}$

$P_{\text {Loss }}$

$P_{\mathrm{NMax}}$

$Q, Q_{1}, Q_{2}$

$Q_{\text {BLoss }}$

$Q_{\text {BNMax }}$

$Q_{\mathrm{P}}$

$Q_{\text {PLoss }}$

$Q_{\text {PLoss,A }}$

$Q_{\text {PNMax }}$

$Q_{\text {PNMax,A }}$

$R_{\mathrm{s}}$

$T_{\mathrm{a}}$

$T_{\mathrm{c}}$

$V, V_{\mathrm{inv}}$

$V_{0}, V_{1}$

$V_{\text {w }}$

$\eta_{\text {inv }}$

$\eta_{\mathrm{m}}$

$\rho$

$\tau \alpha$ acceleration due to gravity $\left(\mathrm{m} / \mathrm{s}^{2}\right)$

total head of the wall system (m) head of drawn well, friction head, pump head, and static head, respectively (m)

hour

frequency

insolation at normal incidence and insolation at incidence angle, respectively $\left(\mathrm{kJ} / \mathrm{m}^{2} / \mathrm{h}\right)$ equivalent friction loss (m) coefficients

pump speed maximum pump frequency $(\mathrm{Hz})$ inverter power output, motor power input, motor power output, and PV power output, respectively (W) unused PV power when storage tank is full and pump is turned off (W)

surplus part of PV power not used by system when maximum pump frequency is exceeded flowrates $\left(\mathrm{m}^{3} / \mathrm{s}\right)$

brine flowrate when $P_{\text {Loss }}$ is used $\left(\mathrm{m}^{3} / \mathrm{h}\right)$

brine flowrate when $P_{\mathrm{NMax}}$ is used $\left(\mathrm{m}^{3} / \mathrm{h}\right)$

permeate flowrate from both $P_{\text {Loss }}$ and $Q_{\text {PNMax }}\left(\mathrm{m}^{3} / \mathrm{h}\right)$

permeate flowrate when $P_{\text {Loss }}$ is used $\left(\mathrm{m}^{3} / \mathrm{h}\right)$

accumulated $Q_{\text {PLoss }}\left(\mathrm{m}^{3}\right)$

permeate flowrate when $P_{\mathrm{NMax}}$ is used $\left(\mathrm{m}^{3} / \mathrm{h}\right)$

accumulated $Q_{\text {PNMax }}\left(\mathrm{m}^{3}\right)$ module series resistance (ohms) ambient temperature $\left({ }^{\circ} \mathrm{C}\right)$ PV cell temperature voltage (V) coefficients velocity $(\mathrm{m} / \mathrm{s})$

efficiency of inverter (per cent) efficiency of motor (per cent) density of water $\left(\mathrm{kg} / \mathrm{m}^{3}\right)$ transmittance absorptance product 